\title{
Contemporary Food Markets within Budapest's Large Housing Estates: Factors Influencing the Design Process
}

AUTHORS:

\section{Melinda Benkő ${ }^{1 *}$ \\ Hlib Antypenko}

\section{Anna Kornélia Losonczy ${ }^{3}$}

1, 2, 3 Budapest University of Technology and Economics (BME), Faculty of Architecture, Department of Urban Planning and Design, Hungary

\section{${ }^{*}$ CORRESPONDING AUTHOR}

E-mail: benko@urb.bme.hu

\section{ARTICLE INFO}

Sent: Dec 29, 2020

Accepted: Jan 28, 2021

\begin{abstract}
:
Food markets provide a continuous urban function at the centre of urban quarters, and their structures are an important component of the local identity. Therefore, they could be crucial in the complex renewal process of a mass housing neighbourhood, indeed. The paper focuses on the contemporary markets within Budapest's three large housing estates, in Újpest Centre, Békásmegyer, and Havanna, opened in 2018, 2019, and 2020 , respectively. The research is based not only on the study of relevant literature, design documents, publications, fieldwork, but also on a survey conducted with three well-recognized Hungarian architects in order to understand and compare their views on the complex context beyond the urban and architectural solutions. The questions focused on the crucial or determining factors of the design process such as the budget, the main players, references, physical context (built and natural), social context, program, and technology. These public projects of varied scale were used for exemplary contemporary food market case studies from Budapest, in which the people involved took into consideration the existing social and material problems and the potential of the heritage of modern mass housing neighbourhoods.
\end{abstract}

\section{KEYWORDS:}

food market, housing estate, urban renewal, design theory, Budapest

\section{ROLE OF THE FOOD MARKETS IN THE URBAN DEVELOP- MENT PROCESS}

Markets - as physical areas for trading goods and food, and for social interactions - have always played an important role within the urban fabric. The long history of food markets dates to preRoman times when this design typology provided a continuous urban function at the centre of urban quarters. [1] In the early modern history, market spaces with neighbouring churches, town halls, guild houses and other forms of civic power were representations of urban progress and modernization. [2] The new wave of markets' development started in the early nineteenth century with the rise of iron and glass markets in Europe. The form and function of markets transformed greatly with the emergence of market halls, arcades, department stores, retail-chains, and other urban shopping practices. These new architectural and urban structures became not only an expression of industrialization power, municipal pride, and technological progress [3] but also an important component of the local identity.
Since the beginning of the 20th century, cities have been gradually transformed, which, in a way, precipitated the decline of the traditional food-markets. Prior to the Second World War period, market halls and outdoor markets - together with farms and market gardens close to the city - fell victim to the inevitable and desirable aspects of modernization, and concepts of the functional zoning based on the idea of "well-planned" city. The postwar urban development strengthened this trend of replacing food-market buildings with inward-oriented department stores, malls, and supermarkets. In addition, today's postmodern cities work with a huge mix of permanent or temporary [4] retail building typologies. Nevertheless, some contemporary urban approaches recognize the importance of the interaction between indoor and outdoor [5], and the role of the food market that could be crucial in the complex process of physical and social renewal of a neighbourhood. Several new contemporary markets try to offer not only good shopping opportunities but also a possibility to meet, socialize, and enjoy some entertainment. [6] 


\section{BUDAPEST FOOD MARKETS}

Budapest is well-known for its historic public market hall ensemble in the city centre: five large covered market halls built in similar style at the end of the $19^{\text {th }}$ century that were opened on the same day, on the February 15, 1897. [7] They provided hygienic and safe facilities, and replaced the open-air temporary markets. [8] However, there were only temporary markets in the transitional and suburban zone [9] of Budapest until WW2. In 1950, the "Greater Budapest" concept was established, in which the aim of the urban planners was to create a polycentric city, transform the adjacent towns into sub-centres, and provide sufficient services in green-field housing estates. This triggered a new wave of socialist retail building construction, however, due to financial reasons, the architectural quality was far below the expected level. [10]

Markets fulfil not only the retail function but they also serve as an important semi-public space within their neighbourhood. They offer not only shopping and meeting opportunities, but also areas for spatial communication, passages [11] among the surrounding public spaces: squares and streets. Nevertheless, in addition to the traditional markets that are the "makers" of cities, there are also contemporary ones that fulfil the same important role. The construction of a new market or the renewal of an older or former one might strongly influence the everyday life in the relevant area. Nowadays, although there is a great variety of urban retail shops and the shopping habits have changed drastically [12], people still prefer to use local food markets. It is peculiar that most market halls in the historic centre have been physically renewed, but struggle with functional crisis, and at the same time, we can experience the "renaissance" of local markets in the outer districts of Budapest that are also undergoing transformation of their own.

The paper focuses on three contemporary market projects implemented within Budapest's large housing estates: in Újpest Centre (2018), in Békásmegyer (2019), and in Havanna (2020). How are these markets positioned in relation to the existing urban fabric of the prefab housing estate? How was the architectural design process influenced by the surrounding urban physical and social context? What architectural and urban qualities do these new markets offer to the housing estates? The research is based not only on the analysis of theoretical literature and design documents, but also on fieldwork and surveys conducted with three well-known Hungarian architects, the designers of the food markets used as case studies. [13]

\section{CONTEMPORARY FOOD MARKETS IN BUDAPEST'S ÚJPEST CENTER, BÉKÁSMEGYER, AND HAVANNA HOUSING ESTATE}

In Budapest, approximately one third of the population currently lives in prefabricated housing estates built during the two 15-year mass housing programs between 1960 and 1990. Out of the forty estates that were realized for more than 20000 inhabitants -the so-called large housing estates - thirteen are situated far from the historic city centre. [15] Since 1990, the year of the economic and political change, there are two levels of governance in Budapest with different competences related to urban development. Both the Budapest municipality and the 23 district governments have elected assemblies and directly elected mayors with a fouryear term in the office. Districts have the general local government authority, while the Municipality of Budapest oversees the urban planning strategy for the capital and tries to coordinate it with the urban planning and design activities of the districts. The main utilities, the public transport system and some public green parks belong to the Budapest Municipality. However, the open spaces and the public buildings within the large prefabricated housing estate areas, that are part of the architectural heritage, without the footprint of the privatized residential buildings, are owned by the districts. So, any maintenance, renewal or development projects are their obligation and their right, indeed. [16]

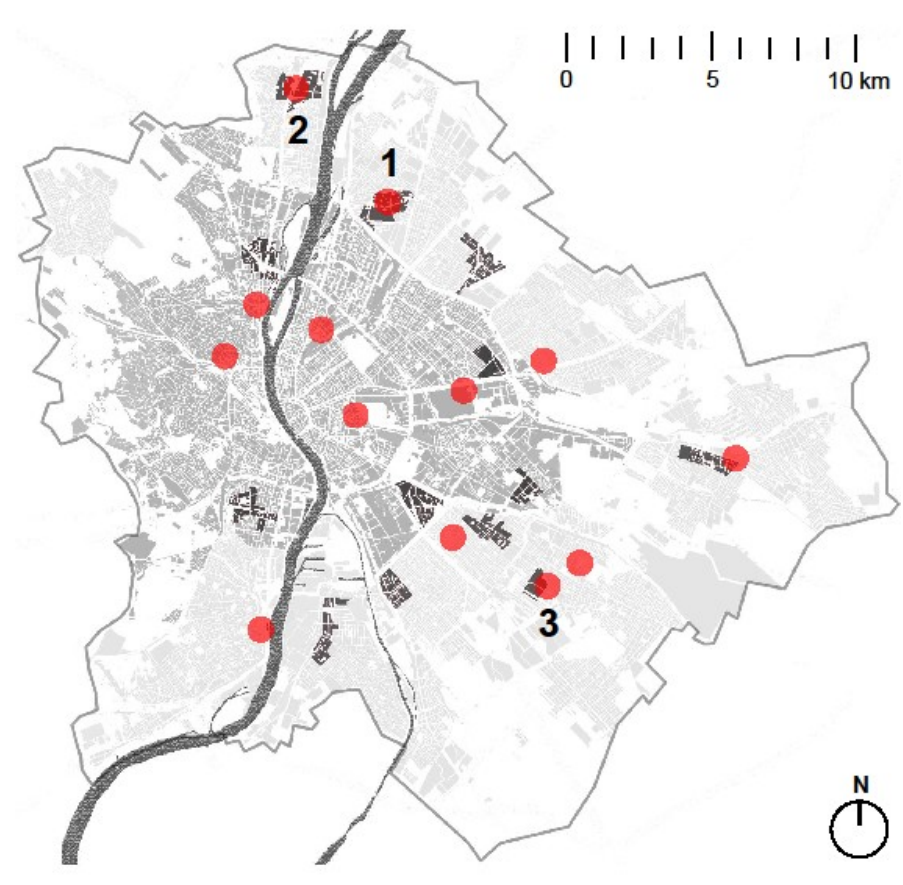

Figure 1: The location of Budapest's 13 large housing estates (in black), contemporary food markets (red dots), and the sites of the three case studies: 1) Újpest Centre 2) Békásmegyer, 3) Havanna (c) Benkö, Antypenko, Losonczy

The implementation of contemporary food market projects could also be considered an important component of the urban renewal process within a housing estate. To summarize the actual situation of Budapest's prefabricated housing estates, it is important to explain the different political and economic background first. [17] In Hungary, basically everything was privatized in the early 1990's, including the flats of the prefab buildings. They were put on the real estate market, the population changed, which was characterized by shrinkage and ageing, but these neighbourhoods remained stigmatized due to their socialist origins. 
Table 1: Basic data on the selected large prefabricated housing estates in Budapest (c) R. Balla (2021) - BME PhD thesis in progress, supervisor: Melinda Benkö [14]

\begin{tabular}{|l|l|l|l|l|l|}
\hline $\begin{array}{l}\text { Budapest districts / dis- } \\
\text { trict name and district } \\
\text { No. }\end{array}$ & Construction period & $\begin{array}{l}\text { Distance from } \\
\text { Budapest centre } \\
\text { / km }\end{array}$ & $\begin{array}{l}\text { Area of the } \\
\text { housing es- } \\
\text { tate / ha }\end{array}$ & $\begin{array}{l}\text { Number of } \\
\text { housing units }\end{array}$ & $\begin{array}{l}\text { Population } \\
\text { density in 2011 } \\
\text { / people / ha }\end{array}$ \\
\hline Újpest Központ / 4 & $1969-88$ & 8 & 161 ha & 16917 & 214 \\
\hline Békásmegyer / 3 & $1971-85$ & 11 & 172 ha & 17973 & 234 \\
\hline Havanna / 18 & $1976-85$ & 10 & 60 ha & 6722 & 230 \\
\hline
\end{tabular}

In 2000, after a decade of neglect, Hungary introduced the "Panel Programs" with the intent to renovate private residential buildings of the housing estates. The programs mainly focused on the technical renovations of prefab buildings with the aim to achieve energy-efficient solutions. [18] After Hungary's admission into the European Union in 2004, the country had the opportunity to apply for various urban programs. Using this framework, some housing estates, for example the Havanna in Budapest, were able to commence their complex renewal, thanks to an "integrated social urban rehabilitation program", co-financed by the EU and the state in 2009. Nevertheless, as they realized that that there were a lot of other sites to develop in Budapest that were much more interesting for private developers than these panel neighbourhoods, every district started to manage and develop their housing estates using various public funds: the European (e.g. complex renewal, main street programs), national (e.g. transport infrastructure development), city of Budapest (public space renewal), or local municipal resources. The contemporary markets, as renewed or new public facilities opened in the last three years, are a visible result of the last step of this challenging process.

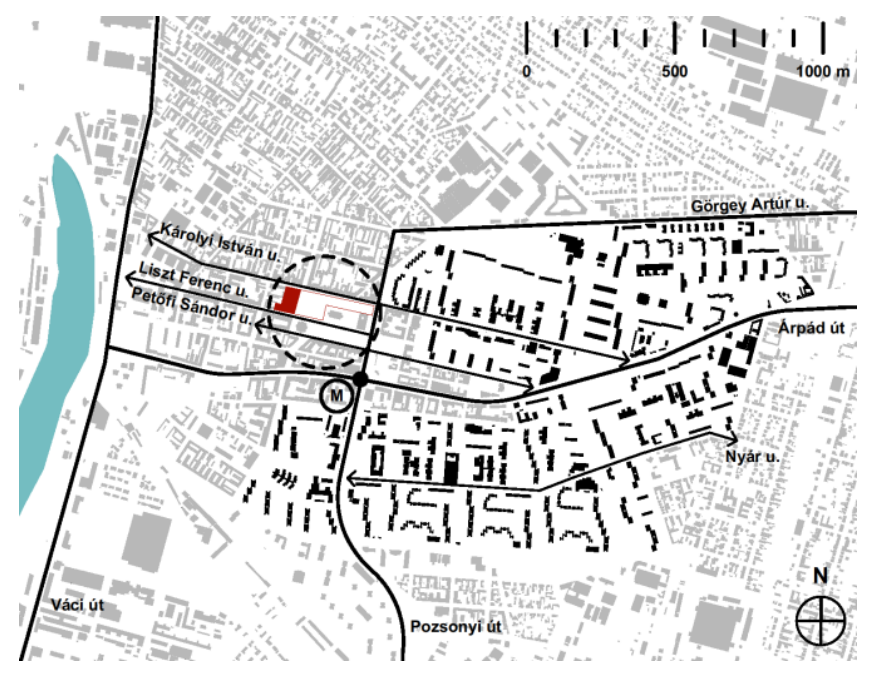

Figure 2: Újpest Centre Housing Estate / black: prefab building, red: contemporary market, M: M3 metro station, circle: $4^{\text {th }}$ district centre and the main pedestrian axes are drawn with arrow.

Újpest is a historic industrial town that became Budapest's $4^{\text {th }}$ district in 1950. Its centre became an important mass housing development. The new modernist masterplan respected some components from the past: several historic public buildings (a Church, the Town Hall and a High School) were preserved, and the historic one- or two-story-high residential/commercial buildings on the two main axes (Árpád and István út) remained intact. In addition, the prefabricated slabs and towers were built in two phases, at the beginning of ' 70 s and ' 80 s, and they did not occupy the former streets, so the tree alleys across the Újpest Centre Housing Estate are a remnant of the past. [19]

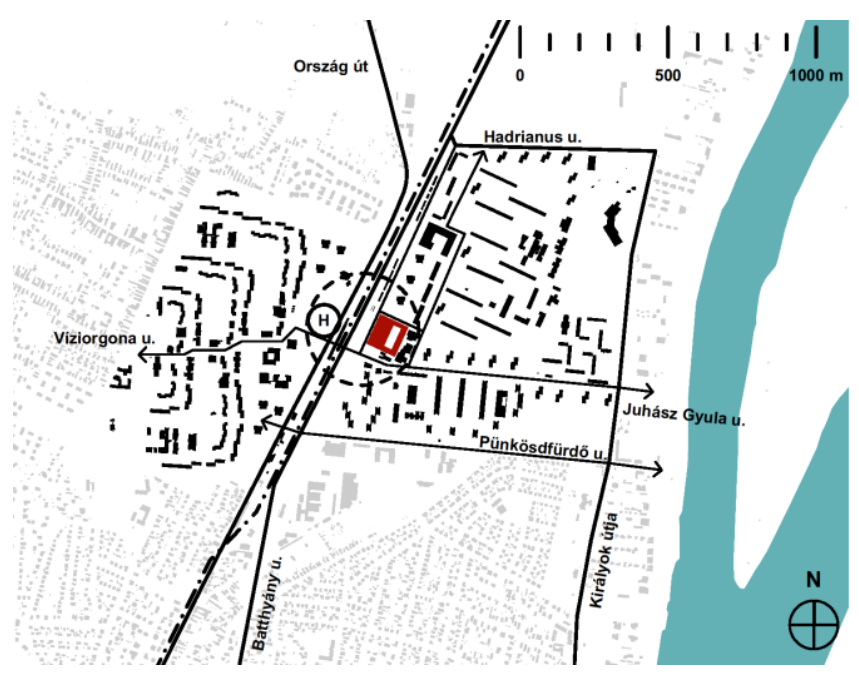

Figure 3: Békásmegyer Housing Estate / black: prefab building, red: contemporary market, $\mathrm{H}$ : $\mathrm{H} 5$ railway station and the main pedestrian axes are drawn with arrow.

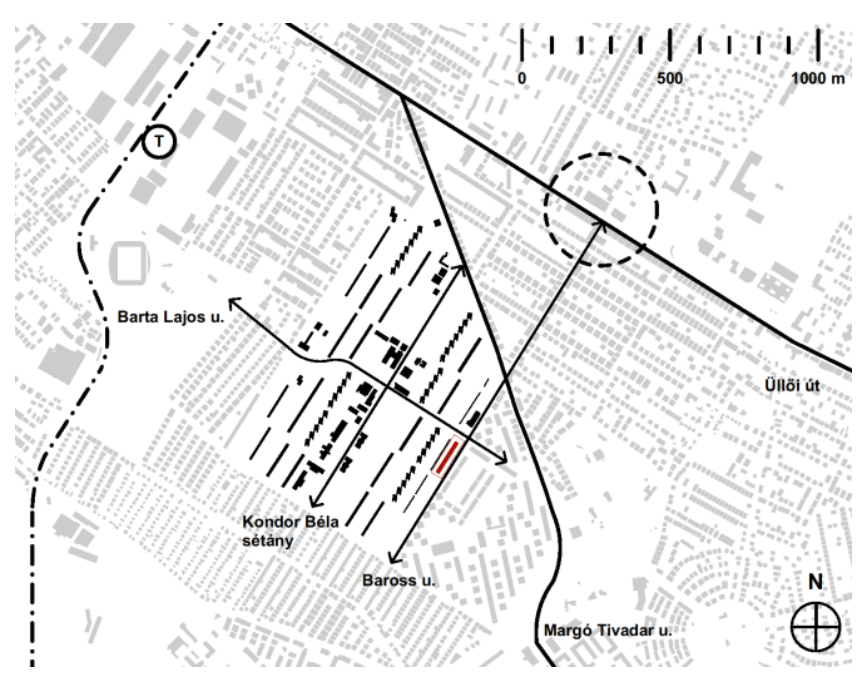

Figure 4: Havanna Housing Estate / black: prefab building, red: contemporary market, circle: $18^{\text {th }}$ district centre and the main pedestrian axes are drawn with arrow.

Figure 2-4 @ Benkö, Antypenko, Losonczy 
Békásmegyer Housing Estate is situated in the Northern part of the $3^{\text {rd }}$ district, on former agricultural land between the Danube and Buda hills. The estate is divided into two parts by a main historic axis, the road connecting Buda and Visegrád, and along this road, the HÉV line (H5 suburban railway) operates between Budapest and Szentendre since 1888. The prefabricated housing estate construction started in 1971 on the Eastern (Danube) side, and later, at the beginning of the ' $80 \mathrm{~s}$, the Western side was completed. The original masterplan projected a huge transport, commercial and cultural HUB in the middle, but it was never realized.

Havanna Housing Estate is a monumental, inhuman and homogenous product of mass-housing production of the '70s, made on the site of a former state colony (slum). The 36 ten-storey-high slabs are organized in a linear manner, and the main axis of the brutalist composition is one of the former colony streets defined by old tree lines. [20] Every public function is located along this $1.00 \mathrm{~km}$-long pedestrian promenade: nurseries, primary schools, a health centre, cultural centre, small historic churches and shops. The edge of the estate is formed by huge open parking areas constituting the border line with the surrounding infinite tissue of detached houses.

\section{URBAN DESIGN OF THE CONTEMPORARY FOOD MAR- KETS IN ÚJPEST CENTER, BÉKÁSMEGYER, AND HA- VANNA HOUSING ESTATE}

Taking into consideration the complexity of markets which are not only architectural products but also important social and cultural entities or the "city makers" - the goal of the paper is to present the three market cases based on the understanding of the design process, discovering its contemporary determining factors. Besides the academic research methods used - literature overview, analysis of design documents, fieldwork - the authors conducted a survey with the well-known Hungarian chief architects who designed these markets (Bun [21], Peschka [22], and Keller). Furthermore, as they are university teachers who specialize in urban design, they have repeatedly worked with students on the architecture of the possible renewal of these large, prefabricated housing estates. [23]

Table 2: Comparative data of the selected three contemporary markets. (c) Benkö, Antypenko, Losonczy

\begin{tabular}{|l|l|l|l|l|l|}
\hline $\begin{array}{l}\text { Budapest districts / } \\
\text { district name and } \\
\text { district No. }\end{array}$ & $\begin{array}{l}\text { Construction } \\
\text { period }\end{array}$ & $\begin{array}{l}\text { Position with } \\
\text { respect to the } \\
\text { prefab housing } \\
\text { estate }\end{array}$ & $\begin{array}{l}\text { Market } \\
\text { building } \\
\text { function }\end{array}$ & $\begin{array}{l}\text { Open space } \\
\text { function }\end{array}$ & $\begin{array}{l}\text { Lead architect who } \\
\text { participated in the } \\
\text { survey / firm }\end{array}$ \\
\hline Újpest Központ / 4 & $2013-18$ & on the edge & $\begin{array}{l}\text { a market hall } \\
\text { and UP! event } \\
\text { space with a } \\
\text { theatre }\end{array}$ & $\begin{array}{l}\text { the main square of } \\
\text { the 4th district }\end{array}$ & $\begin{array}{l}\text { Bun, Zoltán Firka Archi- } \\
\text { tect Studio }\end{array}$ \\
\hline Békásmegyer / 3 & $2012-19$ & in the centre & $\begin{array}{l}\text { a market hall } \\
\text { and small } \\
\text { shops }\end{array}$ & $\begin{array}{l}\text { the main square of } \\
\text { the housing estate }\end{array}$ & $\begin{array}{l}\text { Peschka, Alfréd Óbuda } \\
\text { Group - Architect Studio }\end{array}$ \\
\hline Havanna / 18 & $2016-20$ & on the edge & $\begin{array}{l}\text { small shops } \\
\text { for the weekly } \\
\text { market }\end{array}$ & $\begin{array}{l}\text { an open space mar- } \\
\text { ket / a housing es- } \\
\text { tate parking zone }\end{array}$ & Keller, Ferenc Modulárt \\
\end{tabular}

\section{ÚJPEST CENTER: MARKET HALL AND UP! EVENT-SPACE}

The case of Újpest is special because the implementation of a new market hall project was only one element of a complex renewal program focusing on the district's centre. The Main Square program started in 2007 [24] and the new urban concept was implemented in 2013. The area was divided into four parts following the phasing based on the financial potential. The first phase was a public space renewal around the Town Hall and the Church funded through an EU program. The second one focused on the development of a new market, though not on the square as a stand-alone object building but as integral part of a traditional urban block. [25] The third one would be the renewal of the Northern section, and the fourth one should have been the complex transformation of the Southern part of the area. The new market hall was not planned to replace the former one, but it was to be located on the Western edge of the square as a new, monumental, transparent, high-tech building. The development and the design objectives were complex. On the one hand, the new building had the chance to become a landmark of Újpest's $21^{\text {st }}$ century renewal, a point on the new pedestrian axis between the Danube, the district's centre, and the modern housing estate that would acknowledge the time of the construction by honest architecture based on the aesthetic of the concrete structure. In addition, besides the original food market function it also hosts a cultural centre on the upper floors, the so-called UP! event-space. Compactness, sustainability, community building, mixed-function, 24-hour city, etc. characterize the development. [26] On the other hand, based on the decision mentioned above, the old market hall could fulfil its function during the several years-long construction period. Then, after the opening of the new building complex in 2018, the socialist-era market hall was demolished to 
make space for further development of a public forum with an indoor hall in the centre.

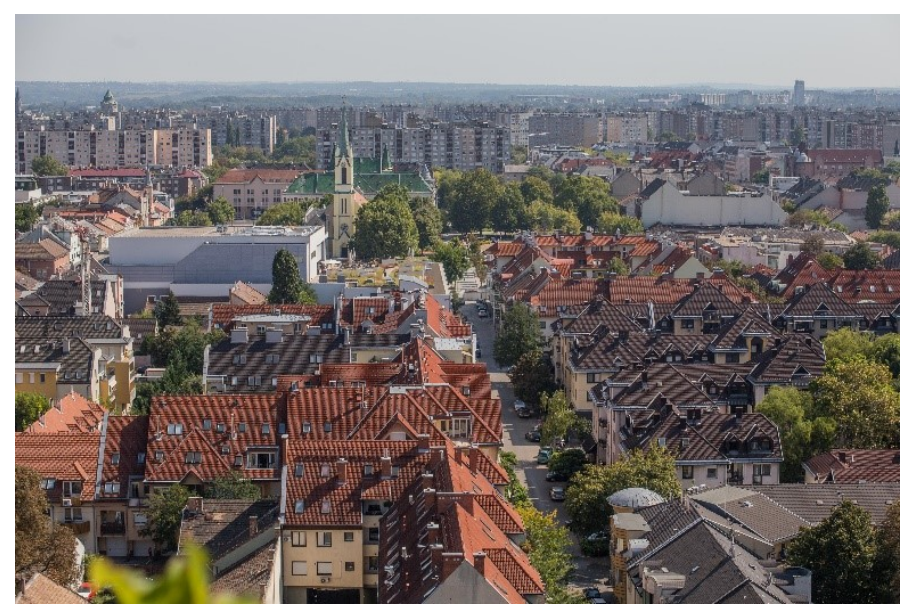

Figure 5: Újpest Centre:

the volume of the new market building, the Church, the Town Hall, and the prefabricated housing estate in the background. C Tamás Fenes, 2020

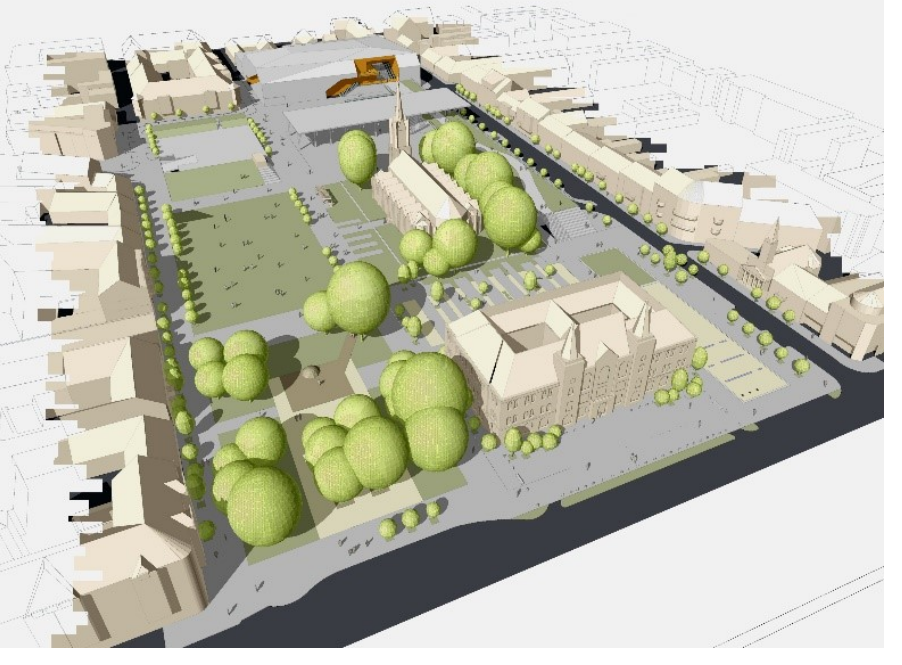

Figure 6: Model of the Újpest Main Square development concept, view from East. (C) Zoltán Bun, 2013

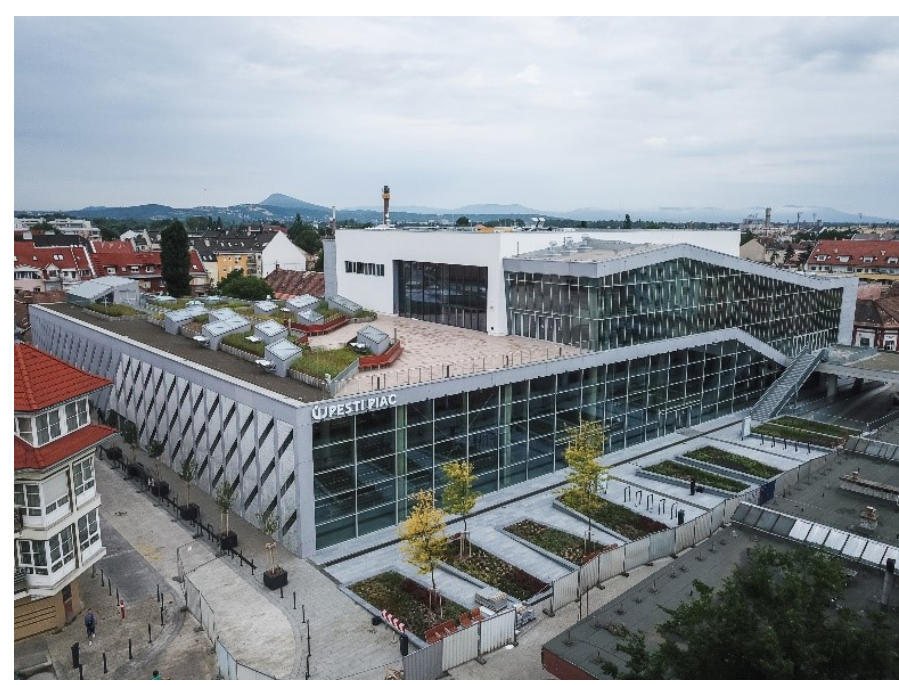

Figure 7: Újpest food market and UP! event-space in the year of its opening.

(C) Emil Magdó, 2018

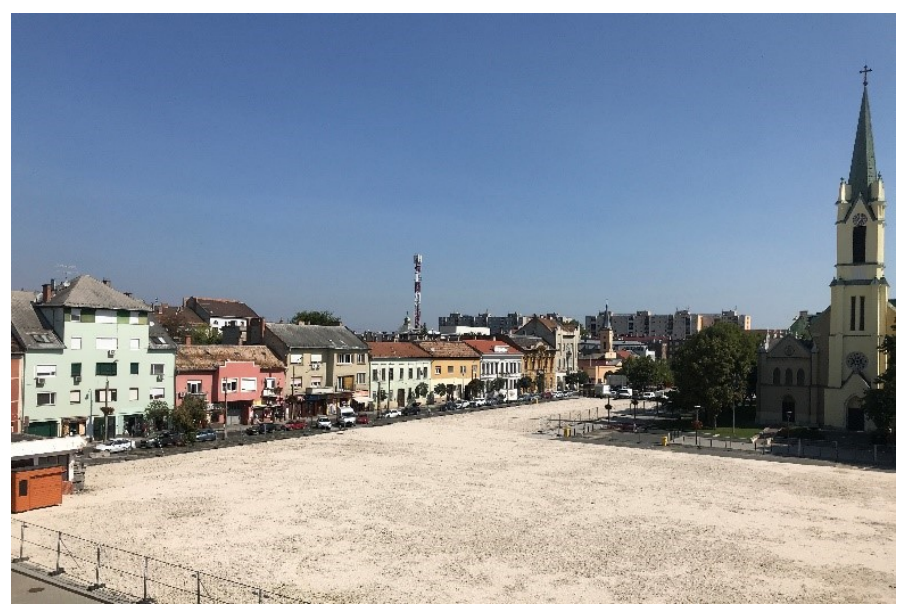

Figure 8: The main square of the $4^{\text {th }}$ district with the land of the former food market, view from the roof-top terrace of the UP! event-space. (C) Melinda Benkö, 2020

\section{BÉKÁSMEGYER: MARKET HALL AND PUBLIC SPACE}

Békásmegyer is a large housing estate that can be classified as a monocentric green-field housing development at the edge of Budapest from the '70s, where the planned multilevel complex centre has never been realized. [27] The large housing estate is divided into two main parts by the circulation axis, and pedestrians must use the approximately 200-meter-long underground passage between the transport HUB and the commercial centre with the market hall. In the ' $80 \mathrm{~s}$, a temporary market hall was built, but eventually it was demolished after only 40 years of its existence to be replaced with a new public development. The objective was not only to create a new building but to reshape neighbouring open space. The renewal process started in 2012, with $80 \%$ of the project financed by the state and the remaining $20 \%$ focusing on the open spaces co-financed by the city of Budapest and the $3^{\text {rd }}$ district's municipality.

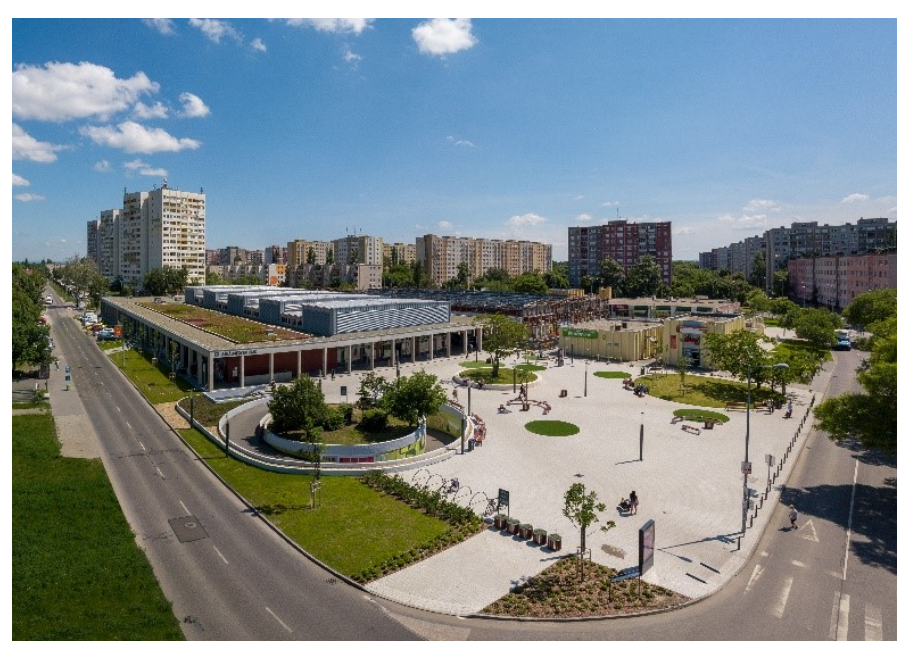

Figure 9: Békásmegyer market area.

C Zsolt Hlinka, 2019

The new project design is inward-oriented on the scale of the housing estate, but obviously offers new opportunities for the residents on a smaller scale, thus increasing the overall liveability of the housing estate. Unlike the previous market building, the contemporary one has facilities for both indoor and outdoor activities and events, but its urban position was changed. Now the main market hall is located along the road, so the new public 
square is protected. It is surrounded by a U-shape arcade providing active façade on every side. Just one year after the market hall opening in 2019, the whole surrounding central area was renewed using direct contrast between buildings and open space design: shapes, materials, colours, etc.

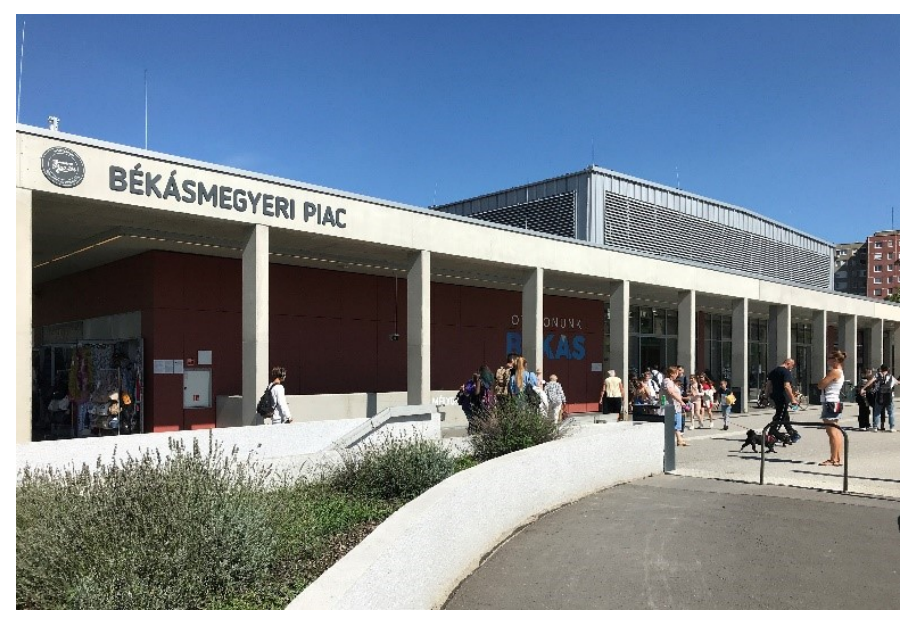

Figure 10: Market hall entrance zone. (C) Melinda Benkő, 2020

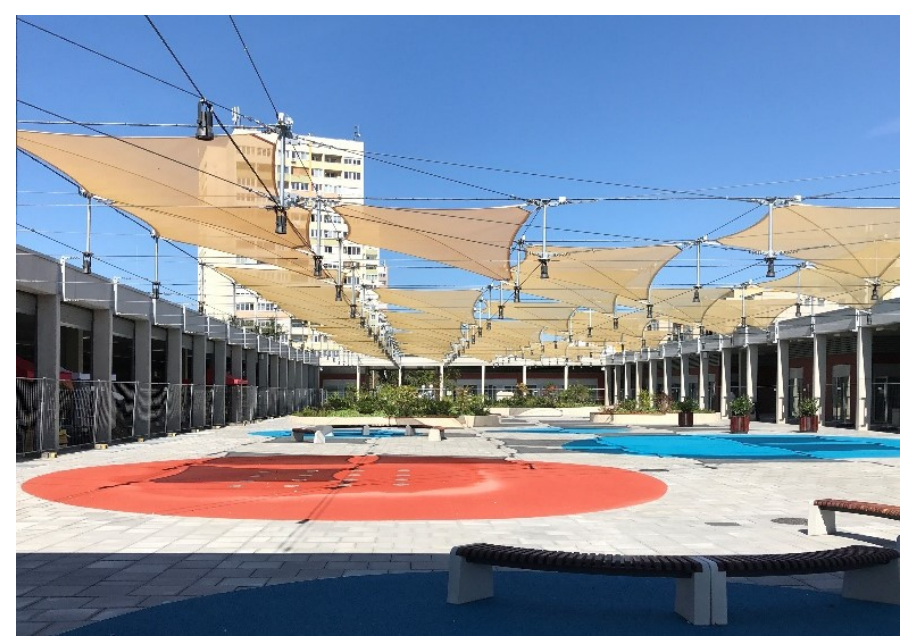

Figure 11: The new public square next to the market hall before its opening. (c) Melinda Benkő, 2020

\section{HAVANNA: OPEN SPACE RENEWAL AND WEEKLY MAR- KET}

The Municipality of Budapest has introduced the TÉR-KÖZ program, a competition system for the 23 districts municipal authorities to earn financial and technical support for public space renewal. [28] The objective is to encourage small local urban interventions - projects that require the cooperation of the district's government and local residents. Thanks to TÉR_KÖZ program, 80 different projects were partly subsidized by the Municipality of Budapest between 2013 and 2018. However, several projects have also been implemented within large, prefabricated housing estates, and Havanna weekly market in the $18^{\text {th }}$ district is one of the best examples.

In 1989, just before the economic and political change, a new conservative party that became the first governor party, the Hungarian Democratic Forum (MDF), facilitated the opening of weekly markets everywhere in the country. [29] These local direct-sale markets became the key component of the MDF's social reform program and as a result, most of the large housing estates started to operate and still operate a Saturday open market in their easily accessible parking areas. A similar car-booth market occupied a part of the parking zone at the edge of Havanna housing estate for decades. In 2016, before the application for Budapest's TÉR_KÖZ call, the $18^{\text {th }}$ district's government conducted interviews with 300 local users of the market, launched a restricted design competition, and defined the program.

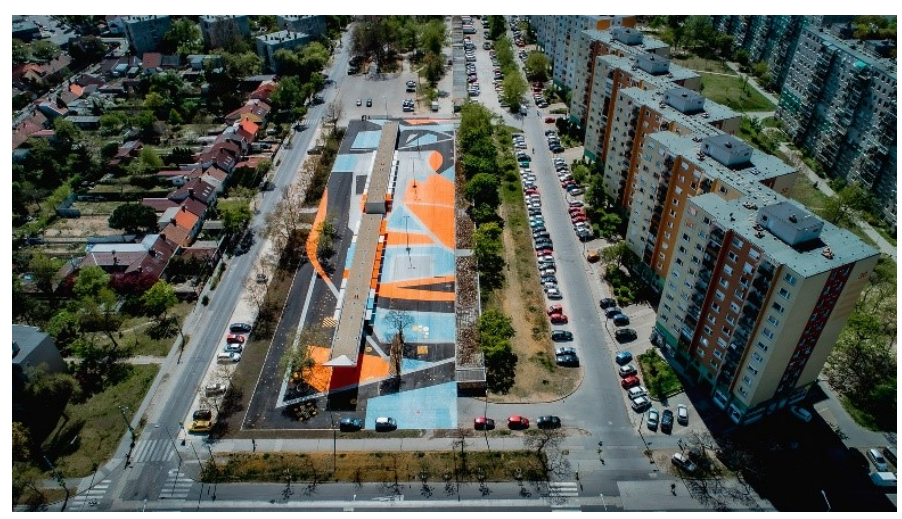

Figure 12: The redeveloped parking area of the Havanna weekly market.

(C) István Ruzsa, 2020

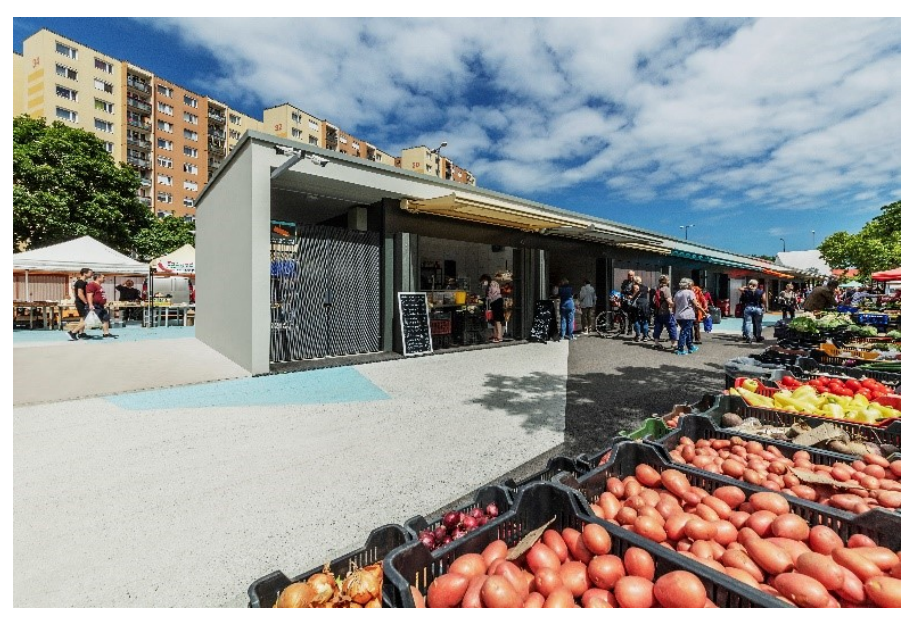

Figure 13: Havanna market on Saturday. (C) Tamás Bujnovszky, 2020

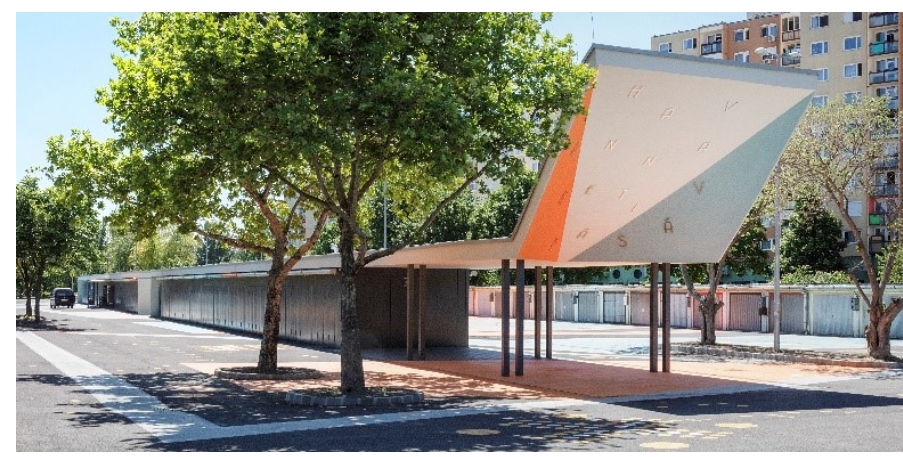

Figure 14: Havanna market on a weekday. (C) Tamás Bujnovszky, 2020

In the original urban design concept, the linear edges of the housing estate were used as parking zones. During the last decade, some new market buildings, sport and dog facilities were 
developed there, but the plot of the weekly market remained intact. This situation changed in April 2020 when the new Havanna weekly market opened. Basic infrastructure of the market is provided for by the simple building that also includes a concrete frame for the kiosks. The intervention is human scaled, transparent, and flexible, but, at the same time, it clarifies the functional rules and introduces contemporary architectural values into the modern neighbourhood. The open space all around and under the building has become a colourful detailed surface integrating existing trees, garages, and parking lanes. The concept was influenced by the strict linear urban structure composed by prefabricated slabs and by an abstract painting made by the Béla Kondor, a name and reference used within the district for years: the central pedestrian axis and the cultural centre of the Havanna housing estate are named after him. The design received an honourable mention on Budapest Architecture Award competition in 2020. [30]

\section{ARCHITECTS' VIEWS ON THE DESIGN PROCESS: INFLU- ENCING FACTORS}

During the state socialism-era of the Central and Eastern European countries, the architects' freedom in the planning, design and construction of the large, prefabricated housing estates was strictly limited. The most important determining factors of their design process were the socialist norms, the types related to urban infrastructure - building, flat, constructive detail and the location; and the personality of the professionals and political players involved. [31] The research explores how this situation has changed, and what the actual determining factors of a project process regarding the renewal of a modern housing estate are. Three case studies from Budapest, new markets opened in the last three years provided an opportunity for a comparative approach. The data is based on the fieldwork, the plan and publication analysis, and online surveys with the lead architects of the contemporary markets, Zoltán Bun (Újpest), Alfréd Peschka (Békásmegyer), and Ferenc Keller (Havanna). It is important to recognize that with regard to the whole process all the three architects described their projects as successful. The project concept provided the fundamental basis for the final project, and during the construction, the concept of the architectural project did not change in any significant manner. We could say that the three markets built in Budapest large housing estates represent exemplary contemporary case studies. The questions focused the following factors influencing or determining the design process: the budget, the people involved, references, physical context (built and natural), social context, program, structure/materials/technology. In the end, architects made a personal ranking showing the importance of these factors with respect to the results. Table 3 summarizes their views and highlights the similarities and the differences.

Table 3: Ranking of the influencing factors of the design process by their relevance.

Source: surveys conducted by the authors

\begin{tabular}{|l|l|l|l|}
\hline & Újpest Központ & Békásmegyer & Havanna \\
\hline 1 & program & built context & built context \\
\hline 2 & people involved & program & budget \\
\hline 3 & budget & social context & program \\
\hline 4 & theory / references & budget & social context \\
\hline 5 & social context & people involved & theory / references \\
\hline 6 & built context & theory / references & natural context \\
\hline 7 & structure / technology / materials & natural context & people involved \\
\hline 8 & natural context & structure / technology / materials & structure / technology /materials \\
\hline
\end{tabular}

\section{PROGRAM - BUDGET}

Naturally, every architectural project always was and still is strongly determined by the program and the budget. The three case studies represent different scale public projects.

Újpest Municipality prepared a long-term urban development concept for the renewal of the district's central area, and the architects actively participated in the preparation of the program brief. They decided to change the position of the market completely. On the one hand, there is much more space, because the new market hall occupies the plot next to the main square and after the demolition of the old market hall on the square itself, this part of the centre could be transformed into a "forum", with open and covered public space. On the other hand, they realized a multifunctional complex "compressed" into one compact multistorey building with important central functions of a city where the food market and the cultural centre try to co-exist in symbiosis where, together, they are to determine the day and night life of the new public space. Unfortunately, two years after the opening of the new market hall and UP! event-space, due to political and economic reasons, most of the original four-phase ambitious renewal project ideas seem to be stopped. The land plot of the 
former food market, the modern building of the flower market, and the huge open space system of the St. Stephen Square are still waiting for their metamorphosis.

In the other two cases, in Békásmegyer and in Havanna housing estate, the program of the market was based on the previous market functions, and the most important new component of the projects has been the surrounding public space development. The renewal of the market building and the open space were conducted simultaneously, and in Békásmegyer, the transformed central area was opened one year after the market hall, whereas in Havanna, it was done at the same time. These districts have undergone a real development using the available stable public fund. Architects considered their projects to be low (Újpest, Havanna) and average cost projects (Békásmegyer).

\section{PHYSICAL CONTEXT}

Context as an architectural term generally refers to the place where buildings are located. [32] However, beyond its physical appearance, architecture is also a cultural field and a social phenomenon; the profession is influenced by new theories, as well as technological and technical innovations.

It is important to recognize that in two cases where the contemporary markets were built within the territory of the modern housing estates (Békásmegyer and Havanna), architects considered the existing built context, the urban fabric of the mass housing neighbourhood to be the most relevant determining factor of their design process. They re-evaluated and reused the modern urban form: the geometric composition, the monumentality of the residential buildings, the existing tree alleys, etc. So, 50 years after these land plots became really urbanized, contemporary architects try to understand and respect this modern urban heritage.

In contrast, in Újpest, where the whole residential area of a historic city centre was demolished to provide space for the prefabricated housing estate, the new developments are more ambitious. The architects want to highlight the contemporary force of the district and they think in terms of large scale and long-term changes. The role of the centre and its building is to give Újpest a unique identity, to attract people from everywhere, not to show the differences between historic, modern, or contemporary residential areas.

\section{SOCIAL CONTEXT}

In Újpest case, architects cooperated very actively with professionals from the local authorities (chief architects, planners, etc.) to develop the urban, and the building concept. In every case the architects had information about the local social context and municipalities organised the required public presentation. Furthermore, when preparing the application for the Tér-Köz competition of the city of Budapest, the $18^{\text {th }}$ district municipality that eventually financed the whole market project, used some participatory tools and conducted surveys to define the program. We can say that these design processes represent classical top-down methods where professionals - designers, and architects from the municipality - are relatively free to define the architectural concepts and the final solutions.

\section{REFERENCES}

The creative freedom is generally influenced by references from the architectural theory, historic or contemporary case studies, and analogies provided by other disciplines. The complex new building of Újpest has been planned by an architect who earned PhD degree in theory of contemporary architecture. He used several resources from all around the world related to urban renewal, space usage [33], markets [34], form, structure, etc. [35] The architect of the Békásmegyer market worked mainly with Hungarian references [36] and case studies. [37] Nevertheless, Havanna project was based on an abstract painting, the Csendélet, made by Béla Kondor in 1962 [38], an artist who has an important role in the $18^{\text {th }}$ district's contemporary image building.

\section{STRUCTURE - MATERIALS - TECHNOLOGY}

The basic material of these three contemporary market buildings is the grey concrete. Comparing the actual situation of the architects with the professional context of the socialist-era mass housing projects, the most interesting result of the surveys is that in every case, the material, structure, and technology were not the determining factors. And now, architects used the same material both within the large modern housing estate where all the slabs and towers were made in grey concrete, and in its surrounding areas. It was a conceptual approach intending to design "honest" architecture, to create transparency using huge glass facades in Újpest, in-between guiding space near the arcades in Békásmegyer, and as a "setting" for the colourful kiosks in Havanna. In Újpest, the exterior and the interior character of the multifunctional building is based on the apparent dominant concrete structure, meanwhile in Békásmegyer and Havanna, the simple geometry, the grey colour and the serenity of the market building create a new order and provide direct contrast to the surrounding active renewed open space where colours, organic shapes, and materials got the main role.

\section{CONCLUSION}

Budapest's thirteen large, prefabricated housing estates were built between 1960 and 1990, and their social and physical context has changed a lot in the last 30 years. However, their real renewal process started only after 2004 , when besides technical renovation of the residential buildings, open space renewal, social programs, and finally some public building construction or reconstruction were introduced. The paper focuses on three contemporary markets in Újpest Centre, Békásmegyer and Havanna housing estates. While during the construction of these modern neighbourhoods, the design was mostly determined by the socialist norms and the prefabricated technology, contemporary architects who work at the edge or within this modern heritage area, besides the program and the budget, consider also the existing social and physical context as one of the most important factors influencing the design. At the beginning of postmodern era, Aldo Rossi, quoting Walter Benjamin, declared, that "I am unquestionably deformed by relationships with everything that surrounds me". [39] Based on the surveys conducted with the architects of the markets, we could say that in these cases, the professionals surpassed the typical functionalist approach of the modern mass architecture worldwide that disregards the local 
context and focuses on the structure, the function, and the form. [40] "Context refers to the fact that most buildings are designed and made for a specific place, the characteristics of which represent many constraints and opportunities in which design is determined... Because architecture cannot detach itself from its context, and because context is never the same, it is essential that knowledge and insight be gained". [41] In consequence, we could argue, that the global products of the $20^{\text {th }}$-century urbanism, the mass housing neighbourhoods, have also local attributes and future-oriented designs use them as their fundamental basis. Planners did not change the position of the markets, not even in the case of Békásmegyer or Havanna, where they "institutionalized" the temporary marketplace. This shows the importance of the location (locus) that - as a part of a complicated socio-spatial network that provides an anchor for the urban fabric [42] - cannot be transferred easily. At the same time, it is important to highlight the responsibility of the main players (designers, decision makers, and residents), because based on the program, the building and the open space design are relatively free. Architects were not limited by any requirements as to the structure, materials, technology, colours, etc. These three markets are made of concrete, the same building material as the prefabricated slabs and towers have, so they are here to stay in their place for a long time. Their contemporary design reflects the local will by the scale of the program and provides not only new aesthetic but also new meanings, thus creating potential for the everyday outdoor and indoor use of the intervention area.

\section{REFERENCES:}

[1] Parham, S. (2005) "Designing the Gastronomic Quarter", Architectural Design, 75(3), pp. 86-95.

https://doi.org/10.1002/ad.81 [DOI]

[2] Stobart, J., Van Damme, I. (2016) "Introduction: markets in modernization: transformations in urban market space and practice, c. 1800 - c. 1970." Urban History, 43(3), pp. 358-371. https://doi.org/10.1017/S0963926815000206 [DOI]

[3] Bassols, M. G., Oyón, J. L. (2015) "Introduction: European Markets as Makers of Cities.” In.: Bassols, M. G., Oyón, J. L. (eds.) Making Cities through Market Halls: Europe, 19th and 20th Centuries, Ajuntament de Barcelona, Museu d'Història de Barcelona, Barcelona, Spain, pp. 11-71.

[4] Kolimárová, S. (2020) "The phenomenon of temporary architecture - its background and potential”, Alfa, 25(3), pp. 3642.

[5] Benkő, M. (2020) "Kint/bent: város és ház találkozása", BME Urbanisztika Tanszék, Budapest. Available at: https://issuu.com/urbanisztikatanszek/docs/benko kintbent

[6] Jones, P., Hillier, D., Comfort, D. (2007) "Changing times and changing places for market halls and covered markets", International Journal of Retail \& Distribution Management, 35(3), pp. 200-209. https://doi.org/10.1108/09590550710735059 [DOI] [7] Török, A. (2014) "Budapest: a Critical Guide", Park Kiadó, Budapest, Hungary

[8] Balázs, B. (2009) "Vásárcsarnokok születése", Múlt-kor. Available at: https://mult-kor.hu/20091215 a vasarcsarnok intezmenye

[9] Budapest zoning system was defined in 1994 and is still valid. See "Budapest 2030 Mid-Term Urban Development Strategy adopted by the General Assembly under Decision Number 923/2014. of 30 June 2013.", Municipality of Budapest, Availa- ble at: https://budapest.hu/Documents/V\%C3\%A1ros\%C3\%A9p\%C3\%ADt\%C3\%A9si\%20F\%C 5\%910szt\%C3\%A1ly/Budapest2030 ENG summary.pdf [10] Preisich, G. (1998) "Budapest Városépítésének Története 1945-1990.", Múszaki Könyvkiadó, Budapest, Hungary.

[11] Apel-Muller, M. (ed.) (2017) "Passages", Actar, Barcelona, Spain.

[12] Tchoukaleyska, R. (2018) "Public places and empty spaces: dislocation, urban renewal and the death of a French plaza", Urban Geography, 39(6), pp. 944-962. https://doi.org/10.1080/02723638.2017.1405872 [DOI] [13] Architects: Bun, Zoltán PhD, Keller, Ferenc (Ybl prize winner in 2003), and Peschka, Alfréd (Ybl prize winner in 2020). The Miklós Ybl prize, established in 1953, is the most prestigious professional award obtainable for architectural activity in Hungary.

[14] Balla, R. (2021) BME PhD thesis in progress, supervisor: Benkő, M.

[15] Losonczy, A., Balla, R., Antypenko, H., Benkő, M. (2020) "Re-Shaping Budapest: Large Housing Estates and their (Un)Planned Centers", Architektúra \& Urbanizmus, 54(1-2), pp. 44-55.

[16] Szabó, B. (2013) "Ten years of housing estate rehabilitation in Budapest", Hungarian Geographical Bulletin 62(1), pp. 113-120.

[17] Benkő, M. (2016) "Budapest's Large Prefab Housing Estates: Urban Values of Yesterday, Today and Tomorrow", Journal of Hungarian Studies, 29(1-2), pp. 21-36.

[18] Szabó, B., Bene, M. (2019) "Budapesti lakótelepek a panelprogram elött és után (Housing estates of Budapest before and after the renovation Programmes.)" Területi Statisztika, 59(5), pp. 526-554. http://doi.org/10.15196/TS590504 [DOI] [19] Ádám, T., Bangha K. (2014) "Újpest akkor és most". Available at: https://www.ujpest.hu/feltolt/ujpest akkor_es most osszes.pdf

[20] The original name of the housing estate was Pestlórinc lakótelep, the architect is Virág, Csaba. Available at:

http://www.urb.bme.hu/tudastar/konyvtar-terkeptar/segedletek/ In 1978, at the time of its opening, the World Festival of Youths and Students was organized in Havanna, Cuba, so the neighbourhood received this name.

[21] Website: https://www.facebook.com/firkastudio

[22] Website: https://obudagroup.hu/projektek/bekasmegyeripiacl

[23] Újpest Center and Havanna were the sites of the Housing Estate in V4, What Next? International workshop in 2015. Available at: http://www.urb.bme.hu/v4/

Békásmegyer is the site of the M1 Urban Design Studio at the Faculty of Architecture, BME, Budapest. Available at: http://www.urb.bme.hu/en/tt3-kiserleti-lakotelep/

[24] Source: https://www.ujpest.hu/foter/ujpest-foter-koncepcio.pdf

[25] Losonczy, A. (2015) "Térnyitás - Az újpesti Egek KiráIynéja Plébániatemplom új parókiája”, Régi-Új Magyar Építőmúvészet, 2015(04), pp. 15-18.

[26] Source: https://www10.aeccafe.com/blogs/arch-showcase/2019/03/10/ujpest-new-market-hall-and-up-event-spacein-budapest-hungary-by-firka-epitesz-studio-kft/

[27] Losonczy, A., Balla, R., Antypenko, H., Benkő, M. (2020) "Re-Shaping Budapest: Large Housing Estates and their (Un)Planned Centers", Architektúra \& Urbanizmus, 54(1-2), pp. 44-55.

[28] Varga, M. (ed.) (2019) "TÉR_KÖZ Budapest - Fővárosi városrehabilitáció 2013-2019”, Budapest Főváros

Önkormányzata, Budapest, Hungary.

[29] More information: https://hu.wikipedia.org/wiki/MDF-piac

[30] More information: http://bpnivodij.hu/ 
[31] Benkő, M. (2019) "Modern Urbanism in Socialist Cities: Architectural and Spatial Qualities of Urban Structure of Mass Housing from the 1960s and 1970s", In: Engel, B. (ed.): Mass Housing in the Socialist City: Heritage, Values, and Perspectives, DOM publishers, Berlin, Germany, pp. 172-181.

[32] Farrelly, L. (2007) "The Fundamentals of Architecture", AVA Publishing, Lausanne, Switzerland.

[33] Skanderbeg Square, Tirana, Albania.

[34] Kravalik, Zs. (2010) "Planning healthy cities - the role of markets in urban life." In: REAL CORP 2010 Proceedings/Tagungsband, pp. 553-565. Available at: https://confer-

ence.corp.at/archive/CORP2010 18.pdf

[35] For example: Diller Scofidio + Renfro: https://dsrny.com/

[36] Cságoly, F. (ed.) (2004) "Középületek", Terc Kiadó, Budapest, Hungary.

[37] E.g.: Sashalom market in the 16th district of Budapest: https://epiteszforum.hu/sose-halunk-meg-a-sashalmi-piac-ujjaszuletese

[38] Source: https://epiteszforum.hu/madar-latta--havanna-hetivasar-mas-nezetben

[39] Rossi, A. (1976) "An Analogical Architecture", In: Jencks, C., Kropf, K. (eds.). Theories and Manifestoes of Contemporary Architecture, Wiley-Academy, West Sussex, England, pp. 66-

67.

[40] Joedicke, J. (1958) "Geschichte der Modernen Architektur”, Auflage, Stuttgart, Germany.

[41] Porter, T. (2004) "Archispeak: An Illustrated Guide to Architectural Terms", Spon Press, London, England.

[42] Roncayolo, M. (1966) "Le "Centre de la ville" à Marseille: notion, contenu, évolution”, In: Urban Core and Inner City: Proceedings of the International Study Week, Amsterdam, The Netherlands, pp. 162-182. 